\title{
A CRIAÇÃo DE MICRORREGIÕES COMO CRITÉRIO PREPONDERANTE NA FILA ÚNICA DE TRANSPLANTE DE ÓRGÃOS: UMA PROPOSTA DE PARTICIPAÇÃO POPULAR POR APROXIMAÇÃO
}

\author{
MICRO REGIONS AS MAJOR CRITERION IN THE \\ LIST OF ORGANS TRANSPLANTATION: \\ A PROPOSAL TO POPULAR PARTICIPATION
}

Adriano Sant'Ana Pedra ${ }^{(*)}$
Diego Pimenta Moraes $^{(*)}$

\section{RESUMO}

A partir do princípio da participação popular, analisam-se o sistema nacional de transplante de órgãos e a atual formação da lista única de receptores, o que permite propor um novo critério de peso na formulação da lista única de receptores de órgãos. Sustenta-se que o critério proposto dá mais transparência ao sistema da fila única, aproxima os possíveis doadores e, por fim, é capaz de sensibilizar mais a população acerca da importância da doação de órgãos e tecidos.

\section{Palavras-chave} de Órgãos.

Direito de Participação; Microrregiões; Sistema Nacional de Transplante

(*) Doutor em Direito Constitucional pela Pontíficia Universidade Católica de São Paulo (PUC/SP); mestre em Direitos e Garantias Constitucionais Fundamentais pela Faculdade de Direito de Vitória (FDV); professor do Curso de Mestrado em Direitos e Garantias Constitucionais Fundamentais da FDV; professor da Escola da Magistratura do Espírito Santo (EMES); Procurador Federal junto à Agência Nacional de Vigilância Sanitária (ANVISA). Vitória/ES-Brasil. E-mail:<adrianopedra@ ig.com.br> $\left.{ }^{(* *}\right)$ Mestrando em Direitos e Garantias Constitucionais Fundamentais pela Faculdade de Direito de Vitória (FDV). Vitória/ES-Brasil. Recebido em 20.08.10. Revisado em 08.09.10. Aprovado em 10.09.10. 


\section{ABSTRACT}

From the principle of participation, the national system of organ transplantation and the current formation of the single list of receivers, is proposed a new criterion of weight in the formulation of the single list of receivers. It is argued that the proposed criterion gives more transparency to the system of single list, close the possible donors and, finally, can sensitize the population to donate organs and tissues.

\section{Keywords}

Brazilian National System of Transplantation; Micro Regions; Right of Participation.

\section{INTRODUÇÃO}

A primeira experiência positiva de implante de órgãos aconteceu em 1954, nos Estados Unidos da América, mais precisamente no Hospital Brigham and Women na cidade de Boston. Na ocasião, o Dr. Joseph E. Murray realizou um transplante de rins entre dois gêmeos. $O$ feito de Murray baseou-se na descoberta de que o genoma de gêmeos era idêntico, o que, no caso da cirurgia, reduziria muito o risco de rejeição(1).

Depois desta primeira experiência positiva, houve significativo estudo em torno do tema e, com o surgimento dos imunossupressores (remédios que evitam a rejeição da troca) na década de 1960, novos horizontes às cirurgias de transplantes foram abertos. Contudo, mesmo diante dessa evolução, os riscos eram altos e as chances de sobrevivência após a cirurgia eram baixos.

Em 1967, o primeiro transplante de coração foi realizado na Cidade do Cabo, na África do Sul, pelo médico Christian Barnard. O fato do paciente ter falecido dezoito dias após a cirurgia não chegou a ofuscar o efeito; pelo contrário, corroborou a possibilidade de êxito no procedimento.

Com o êxito do procedimento comprovado e os estudos sobre o tema acelerados, na década de 80 houve significativo avanço na qualidade dos medicamentos imunossupressores, de forma que a prática de transplantes de órgãos e tecidos se tornou rotineira. Todavia, restavam ainda grandes barreiras: a falta de informação e o preconceito.

(1) DINIZ, Maria Helena. O estado atual do biodireito. 3. ed. São Paulo: Saraiva, 2006. p. 311. 
No Brasil, a atividade de transplante de órgãos e tecidos iniciou-se na década de 60. A primeira lei regulamentando o transplante de órgãos data de 1968. Adiante, em 18 de novembro de 1992, foi editada uma segunda lei sobre o sistema de transplante de órgãos no Brasil, a Lei n. 8.489. Em 4 de fevereiro de 1997, foi publicada a Lei n. 9.434, que aprimorou e atualizou a lei originária. Esta lei, conforme descreve seu caput, dispõe sobre a remoção de órgãos, tecidos e partes do corpo humano para fins de transplante e tratamento e dá outras providências. Por fim, foi editada a Lei n. 10.211, em 23 de março de 2001, que alterou alguns dispositivos importantes da Lei n. 9.434.

Atualmente, mais de 69.000 (sessenta e nove mil) brasileiros estão na fila dos transplantes ${ }^{(2)}$ Muitos ainda conseguem levar uma vida relativamente normal, apesar da rotina de sofrimento físico que, dentre outras provações, envolve doses altíssimas de medicamentos, a dependência de equipamentos como máquinas de diálise, cilindros de oxigênio e a necessidade de cuidados médicos constantes. Para outros, a vida está por um fio.

Mais de cinco décadas se passaram desde a realização do primeiro transplante. Com o avanço das técnicas e o aprimoramento de drogas contra a rejeição, hoje muitos órgãos do corpo humano são passíveis de substituição. Esta é uma das maiores conquistas da medicina e o Brasil não deixa a desejar. O país tem hoje o maior sistema público de transplantes do mundo e o esquema de filas organizado. Existem, no entanto, oportunidades de melhorias para que mais vidas sejam salvas.

Tirando a parte estrutural, os maiores desafios do sistema de transplantes nacional residem na busca por novos doadores e na organização de uma lista de espera transparente, com critérios justos. A participação popular no processo de composição da lista de receptores pode apresentar soluções importantes para esses desafios. Neste sentido, analisa-se como proposta de solução a criação de microrregiões para privilegiar o transplante em âmbito local, por uma desejável participação popular, ocasionando a aproximação do povo ao Estado gestor da fila.

\section{PARTICIPAÇÃO POLÍTICA}

A Constituição da República Federativa do Brasil de 1988, no caput do seu art. 1ำ, definiu o Estado brasileiro como um Estado Democrático de Direito. A ideia de um Estado Democrático de Direito ou de um Estado Constitucional da Democracia participativa, como também é conhecido, remete, em primeiro lugar, à forma de governo, ou seja, quem governa e como se governa o

(2) MINISTÉRIO DA SAÚDE. Disponível em <http://www.adote.org.br/pdf/lista0607.pdf>. Acesso em: 23 jul. 2010. 
Estado. No entanto, como bem define Jean Rivero(3), a democracia não é apenas um método de eleger ou designar quem deverá ser exercido.

Neste giro, convém destacar que a democracia como elemento formador do conceito de Estado Democrático de Direito pressupõe um "processo de convivência social numa sociedade livre, justa e solidária (art. $3^{\circ}$, I), em que o poder emana do povo, e deve ser exercido em proveito do povo, diretamente ou por representantes eleitos (art. 1ํㅡㄹ parágrafo único)"(4).

Dentro deste contexto, firma-se que uma vez qualificado o Estado como democrático, tal caractere irradia-se sobre todos os seus elementos de formação e de atuação, de forma que o crivo para a legitimidade de qualquer ação ou política estatal passa a ser a vontade soberana do povo exercida pelos meios legais. Daí deflui a ideia de participação popular.

No Estado democrático de direito, a participação política é o pressuposto para conferir-Ihe o caráter democrático. Nesse contexto, como bem assevera Augustin Gordillo a "democracia, ela própria, é um sinônimo de participação". ${ }^{(5)}$

A participação política é o meio pela qual o povo participa do processo decisório, em adstrição ao disposto no parágrafo único do art. 1ำ da CRFB, segundo o qual "todo o poder emana do povo, que o exerce por meio de representantes eleitos ou diretamente, nos termos desta Constituição".

Logo, a participação popular é instrumento para conferir legitimidade às decisões e esta legitimidade é uma qualidade do exercício do poder. "Democracia e participação se exigem, não havendo democracia sem participação"(6). Consequentemente, espera-se que o interesse coletivo seja permanentemente satisfeito pelos detentores do poder ${ }^{(7)}$. Em termos práticos, todavia, a legitimidade é verificada na adequabilidade do exercício do poder à cura dos interesses coletivos da sociedade. Assim, quanto mais atender aos anseios da sociedade, mais legítimas serão as decisões tomadas pelo governo.

Com efeito, a maior importância da participação política está no fato de que, por intermédio dela, resta transparente a adequação do agir do Estado aos interesses predominantes na sociedade que organiza e dirige.

Neste sentido, a participação política deve ser entendida como toda atuação, formal e informalmente admitida, dos indivíduos e dos grupos sociais secundários, na ação juspolítica do Estado.

(3) RIVERO, Jean; apud MOREIRA NETO, Diogo de Figueiredo. Direito da participação política. Rio de Janeiro: Renovar, 1992. p. 19.

(4) SILVA, José Afonso da. Curso de direito constitucional. 30. ed. São Paulo: Malheiros, 2008. p. 119.

(5) GORDILLO, Agustin. Participation in Latin America. Nova York: Vintage Press, 1982. p. 1.

(6) PEDRA, Adriano Sant'Ana. A Constituição viva: poder constituinte permanente e cláusulas pétreas. Belo Horizonte: Mandamentos, 2005. p. 257.

(7) MOREIRA NETO, Diogo de Figueiredo. op. cit., p. 26. 
No Estado Democrático de Direito, o que se almeja com a participação popular não é a mera conquista de novos direitos, mas sim a efetiva participação do povo no processo político decisório, de forma a controlar a eficiência e legitimar atuação da Administração Pública.

\section{DIREITO À SAUDE}

Da mesma forma que definiu a participação política como requisito de legitimidade e eficácia das decisões adotadas pelo Poder Público, a Constituição da República Federativa do Brasil de 1988 consagrou expressamente a saúde como direito fundamental. Atendendo às reivindicações do Movimento de Reforma Sanitária, o texto constitucional de 1988 foi além da simples definição da saúde como direito fundamental. Ele expressamente detalhou o sistema único de saúde como meio procedimental de se efetivar o direito fundamental constitucionalmente garantido.

Neste sentido, é de bom alvitre destacar que a atribuição de contornos próprios ao direito fundamental à saúde correlacionado à garantia de assistência social foi exatamente um dos marcos da sistemática introduzida em 1988, rompendo com a tradição de frágil abordagem sobre o tema nos textos constitucionais anteriores.

Ademais, a explicitação constitucional do direito fundamental à saúde, bem como a criação do Sistema Único de Saúde (SUS), decorrem, assim, da evolução dos sistemas de proteção antes instituídos em plano ordinário (do Sistema Nacional de Saúde, criado pela Lei n. 6.229/75 e, já em 1987, do Sistema Unificado e Descentralizado de Saúde - SUDS).

Sob a exegese do ordenamento jurídico brasileiro, o direito à saúde comunga da dupla fundamentalidade formal e material da qual se revestem os direitos e garantias fundamentais em geral, especialmente em virtude do regime jurídico privilegiado que Ihes outorgou a Constituição de 1988. Na lição de Ingo Wolfgang Sarlet e Mariana Filchtiner Figueiredo, a fundamentalidade material

encontra-se ligada à relevância do bem jurídico tutelado pela ordem constitucional, que se evidencia pela importância da saúde como pressuposto à manutenção da vida - e vida com dignidade, ou seja, vida saudável e com certa qualidade -, assim como para a garantia das condições necessárias à fruição dos demais direitos, fundamentais ou não, inclusive no sentido de viabilização do livre desenvolvimento da pessoa e de sua personalidade. ${ }^{(8)}$

(8) SARLET, Ingo Wolfgang; FIGUEIREDO, Mariana Filchtiner. Algumas considerações sobre o direito fundamental à proteção e promoção da saúde aos 20 anos da Constituição Federal de 1988. Revista de Direito do Consumidor, São Paulo, n. 67, p. 132, jul./set. 2008. 
Já a fundamentalidade no sentido formal, consoante lição dos autores, decorre do direito constitucional positivo e na Constituição da República Federativa do Brasil desdobra-se em três elementos, a saber: (I) como parte integrante da Constituição escrita, os direitos fundamentais (e, portanto, também o direito à saúde), situam-se no ápice de todo o ordenamento jurídico, cuidando-se, pois, de normas de superior hierarquia axiológica; (ii) na condição de normas fundamentais estabelecidas na Constituição escrita, encontram-se submetidos aos limites formais (procedimento agravado para modificação dos preceitos constitucionais) e materiais ("cláusulas pétreas") da reforma constitucional; (iii) por derradeiro, nos termos do que dispõe o $\S 1^{\circ}$ do art. 5 da CRFB/1988, as normas definidoras de direitos e garantias fundamentais são diretamente aplicáveis, vinculando de forma imediata as entidades estatais e os particulares ${ }^{(9)}$.

Além da previsão do direito à saúde como direito fundamental, o texto constitucional brasileiro também estabelece que a tutela jusfundamental da saúde efetiva-se como um dever do Poder Público, haja vista a redação do art. 196 da CRFB, segundo a qual "a saúde é direito de todos e dever do Estado".

Sem prejuízo de outras possíveis concretizações, é de se destacar que, no plano da dimensão prestacional, o dever do Estado de promoção à saúde se concretiza pelas normas e políticas públicas de regulamentação e organização do Sistema Único de Saúde (SUS), especialmente no que concerne ao acesso ao sistema, à participação da sociedade na tomada de decisões, bem como no programa nacional de transplante de órgãos.

No ordenamento jurídico brasileiro, a constitucionalização do SUS tanto densifica a dimensão objetiva do direito à saúde, quanto representa verdadeira garantia institucional fundamental, pois a própria Constituição brasileira cuidou de regular suas principais diretrizes e princípios.

Neste sentido, deve-se destacar que os princípios que regem o SUS e a política nacional de saúde são extraídos dos arts. 198 a 200 da Constituição Federal, a saber: princípio da unidade, princípio da descentralização, princípio da regionalização, princípio da hierarquização, princípio da integralidade e princípio da participação da comunidade.

Vale mencionar que no bojo da disciplina constitucional do SUS, o texto constitucional consagra, ainda, a política nacional de transplante de órgãos, ex vi da redação do $\S 4^{\circ}$ do art. 199 da CRFB, segundo o qual "a lei disporá sobre as condições e os requisitos que facilitem a remoção de órgãos, tecidos e substâncias humanas para fins de transplante, pesquisa e tratamento, bem como a coleta, processamento e transfusão de sangue e seus derivados, sendo vedado todo tipo de comercialização".

(9) SARLET, Ingo Wolfgang; FIGUEIREDO, Mariana Filchtiner.op. cit. p. 132. 
Com efeito, malgrado o texto constitucional tenha dedicado tímida disciplina à política nacional de transplantes ${ }^{(10)}$, nota-se que há permissão para o transplante de órgãos, tecidos e partes do corpo humano tanto entre vivos quanto após a morte do doador. Na doação inter vivos, o ato é realizado intuitu personae, isto é, entre doador e receptor individualizado, sempre de forma gratuita ${ }^{(11)}$. Na hipótese de disposição de órgãos post mortem, os órgãos são disponibilizados para uma lista única de espera.

Conforme abaixo se alinhavará, o sistema nacional de transplante de órgãos brasileiro constitui-se em complexa estrutura organizacional que, para maior eficácia e legitimidade de seu funcionamento, imprescinde de abertura e participação popular.

\section{Sistema nacional de transplante de orgãos}

\subsection{A organização administrativa}

A política nacional de transplantes de órgãos e tecidos funda-se na Lei n. 9.434/97, com alteração da Lei n. 10.211/01. As diretrizes adotadas por este complexo legislativo são: (i) gratuidade da doação; (ii) beneficência em relação aos receptores; e (iii) preservação da integridade dos doadores vivos.

O Sistema Nacional de Transplantes, desde sua criação (1997), tem como prioridade evidenciar com transparência todas as suas ações no campo da política de doação-transplante, objetivando primordialmente a confiabilidade do Sistema e a assistência de qualidade ao cidadão brasileiro(12).

No plano organizacional, é de bom alvitre destacar que, o Brasil possui atualmente um dos maiores programas públicos de transplantes de órgãos e tecidos do mundo. São mais de 555 estabelecimentos de saúde e 1.376 equipes médicas autorizadas pelo Sistema Nacional de Transplantes (SNT) a realizar transplante. Ademais, ainda neste complexo organizacional, o SNT está presente, por intermédio das Centrais Estaduais de Transplantes (CNCDO's), em 25 estados da Federação(13).

(10) Da mesma forma, ainda é incipiente o desenvolvimento teórico do tema. Cf. LEITE, Carlos Henrique Bezerra. Os direitos da personalidade na perspectiva dos direitos humanos e do direito constitucional do trabalho. Depoimentos - Revista de Direito das Faculdades de Vitória, Vitória, n. 9, p. 57, jan./dez. 2005: "Os transplantes criaram uma revolução nos direitos sobre o próprio corpo, não havendo ainda uniformidade jurídica na matéria, que é recentíssima."

(11) PEDRA, Adriano Sant'Ana. Transplantes de órgãos e o biodireito constitucional. Revista de Direito Constitucional e Internacional, São Paulo, ano 15, n. 61, p. 18, out./dez. 2007.

(12) MINISTÉRIO DA SAÚDE. Sistema Nacional de Transplantes. Disponível em: <http:// snt.datasus.gov.br/ SNT/index.jsf>. Acesso em: 22 jul. 2010.

(13) Id. Ibid. 
A movimentação deste sistema requer densa e complexa organização administrativa. O Sistema Nacional de Transplantes, tal como o próprio Sistema Único de Saúde (SUS), se rege pela colaboração de todos os entes federados. Assim, ainda na organização estrutural do sistema, verifica-se que a intenção do Poder Público foi concatenar estruturas e medidas organizacionais em todos os âmbitos federativos, a saber: federal, estadual (ou distrital) e municipal.

Como acima mencionado, o marco regulatório do Sistema Nacional de Transplante (SNT) de órgãos é a Lei n. 9.434/97. Tal lei, todavia, estabelece apenas as diretrizes gerais; desta forma, a regulamentação administrativa do SNT ficou a cargo do Decreto n. 2.268, de 30 de outubro de 1997 e do ato Normativo n. 2.600, de 21 de outubro de 2009 (aprimorou todo o Sistema Nacional de Transplante e as estruturas a eles ligadas, mediante a criação do Regulamento Técnico do Sistema Nacional de Transplantes).

Administrativamente, a primeira providência adotada pelo Decreto n. 2.268/97 foi a criação do Sistema Nacional de Transplantes (SNT), que, consoante dispõe 0 art. $2^{\circ}$, tem a atribuição de desenvolver o processo de captação e distribuição de tecidos, órgãos e partes retirados do corpo humano para finalidades terapêuticas, e, tem como âmbito de intervenção as atividades de conhecimento de morte encefálica verificada em qualquer ponto do território nacional e a determinação do destino dos tecidos, órgãos e partes retirados.

Em termos de organização funcional, o SNT é formado pela união do Ministério da Saúde, das Secretarias de Saúde dos Estados e do Distrito Federal (ou órgãos equivalentes), das Secretarias de Saúde dos Municípios (ou órgãos equivalentes), dos estabelecimentos hospitalares autorizados e da rede de serviços auxiliares necessários à realização de transplantes.

Nos moldes da Portaria n. 2.600/09, o Ministério da Saúde, por intermédio da Coordenação Geral do Sistema Nacional de Transplantes (CGSNT), do Departamento de Atenção Especializada (DAE), da Secretaria de Atenção à Saúde (SAS), exerce a função de órgão central do Sistema Nacional de Transplantes. Impende destacar que a CGSNT tem atuação no âmbito federal e sua criação teve como principal meta a harmonização das políticas nacionais do sistema de transplante e a articulação do SNT com os outros órgãos do Ministério da Saúde.

Ainda no âmbito federal, e para o exercício das funções que competem ao órgão central do SNT, foi criado o Grupo de Assessoramento Estratégico (GAE), cujo objetivo principal é assistir a CGSNT. Para assessoramento técnico, a CGSNT conta com inúmeras Câmaras Técnicas Nacionais (CTNs), a saber: CTN de Captação e Doação de Órgãos, Tecidos, Células e Partes do Corpo; CTN de Histocompatibilidade; CTN de Transplante de Coração; CTN de Transplante de Pulmão; CTN de Transplante de Fígado; CTN de Transplante de Pâncreas; CTN de Transplante de Rim; CTN de Transplante 
de Células-Tronco Hematopoéticas; CTN de Transplante e Banco de Tecidos Oculares; CTN de Transplante e Banco Multitecidos (pele, tecidos cardiovasculares e tecidos musculoesqueléticos); e CTN de Ética e Pesquisa em Transplantes.

Já para a execução das atividades de coordenação de logística e distribuição de órgãos e tecidos no processo de doação/transplante em âmbito nacional, a CGSNT conta com a Central Nacional de Transplantes (CNT), cujas principais atribuições são: (i) a articulação com os demais integrantes do Sistema Nacional de Transplantes; (ii) o apoio ao gerenciamento da captação, dando suporte técnico e intermediação necessários à busca, em todo o território nacional, de tecidos, órgãos e partes do corpo humano nas situações em que as condições clínicas do doador, o tempo de isquemia fria e as condições de acessibilidade a permitam; e (iii) o gerenciamento da alocação de órgãos e tecidos entre Estados, em conformidade com a lista nacional de potenciais receptores, procurando otimizar as condições técnicas de preservação, transporte e distribuição; considerando os critérios estabelecidos na legislação em vigor, de forma a garantir o melhor aproveitamento dos órgãos disponíveis e a equidade na sua destinação.

No processo de alocação de órgãos, a CNT se divide em 4 (quatro) macrorregiões: Região I - Rio Grande do Sul, Santa Catarina e Paraná; Região II — Rio de Janeiro, Minas Gerais e Espírito Santo; Região III — Goiás, Mato Grosso do Sul, Mato Grosso, Distrito Federal, Tocantins, Amazonas, Pará, Acre, Roraima, Rondônia, Amapá e São Paulo; e Região IV — Bahia, Sergipe, Alagoas, Pernambuco, Paraíba, Rio Grande do Norte, Ceará, Maranhão e Piauí.

A complexa organização do Sistema Nacional de Transplantes no âmbito federal, também se desdobra nas unidades federativas. As Coordenações Estaduais do SNT são exercidas pelas Secretarias de Saúde dos Estados e do Distrito Federal, ou órgãos equivalentes, por intermédio das respectivas Coordenações Estaduais ou Distrital de Transplantes.

Para que se integrem ao SNT, conforme o disposto no art. $5^{\circ}$ do Decreto n. 2.268/97, os Estados e o Distrito Federal que possuam em seu território equipes especializadas e estabelecimentos de saúde autorizados para realizar diagnóstico de morte encefálica, retirada de órgãos e tecidos e transplantes e enxertos, deverão instituir Centrais de Notificação, Captação e Distribuição de Órgãos (CNCDO's).

As Centrais de Notificação, Captação e Distribuição de Órgãos (CNCDO's) são as unidades executivas das atividades do SNT, afetas ao Poder Público, cujas principais atribuições são: coordenar as atividades de transplantes no âmbito estadual; promover a inscrição de potenciais receptores, com todas as indicações necessárias à sua rápida localização e à verificação de compatibilidade do respectivo organismo para o transplante ou enxerto; classificar 
os receptores e agrupá-los segundo suas especificidades, e em ordem estabelecida pela data de inscrição; comunicar ao órgão central do SNT as inscrições que efetuar para a organização da lista nacional de receptores; receber notificações de morte encefálica ou outra que enseje a retirada de tecidos, órgãos e partes para transplante, ocorrida em sua área de atuação; determinar o encaminhamento e providenciar o transporte de tecidos, órgãos e partes retirados ao estabelecimento de saúde autorizado, em que se encontrar o receptor ideal; notificar o órgão central do SNT de tecidos, órgãos e partes não aproveitáveis entre os receptores inscritos em seus registros, para utilização dentre os relacionados na lista nacional.

Ademais, competem exclusivamente às CNCDO's as atividades relacionadas ao gerenciamento do cadastro de potenciais receptores, recebimento das notificações de mortes encefálicas, promoção da organização logística e distribuição dos órgãos e/ou tecidos removidos na sua área de atuação.

\subsection{O processo de doação}

Conforme dito anteriormente, a distribuição de órgãos e tecidos doados é responsabilidade da Central de Notificação, Captação e Distribuição de Órgãos e Tecidos de cada Estado (CNCDO). Vale destacar que, para melhor articulação e distribuição de órgãos entre os Estados de forma a garantir o melhor aproveitamento dos órgãos disponíveis e a equidade na sua destinação, também foi criada a Central Nacional de Notificação, Captação e Distribuição de Órgãos, que funciona no aeroporto de Brasília.

A distribuição de órgãos e tecidos consiste na etapa de definição dos receptores para cada órgão/tecido doado e transporte deste. Essa etapa inicia-se com a identificação de um potencial doador de órgãos e finda-se com o transplante propriamente dito. Em outros termos, a identificação de uma pessoa com morte encefálica (potencial doador) em um hospital marca o início de um processo que poderá culminar com a doação de órgãos.

A identificação propriamente dita pressupõe uma avaliação médica e a realização dos exames clínicos e Complementares do Termo de Declaração de Morte Encefálica (Resolução n. 1.480, de 08.08.1997). A propósito, esclareça-se que o conceito de morte encefálica apareceu inicialmente em 1959, com o termo "coma depassé" que descrevia um estado de morte do cérebro anterior à morte do corpo. Em 1968, uma comissão da Faculdade de Harvard, nos Estados Unidos, definiu o conceito de coma irreversível. Até então, a morte era associada à parada dos batimentos cardíacos.

No Brasil, o Conselho Federal de Medicina (CFM) editou a Resolução n. 1.346/91, estabelecendo critérios para o diagnóstico de morte encefálica, que foram posteriormente revistos pela Resolução n. 1.480/97. Para a 
comprovação do diagnóstico de morte encefálica é necessária a realização de exames clínicos e complementares. Os exames clínicos devem ser feitos por no mínimo dois médicos, sendo um deles neurologista/neurocirurgião. Esses médicos não podem ser integrantes da equipe de transplante. Os exames complementares podem ser o eletroencefalograma, angiografia cerebral de quatro vasos, dentre outros. Todo o processo pode ser acompanhado por um médico de confiança da família do doador.

Diante da identificação de um potencial doador, o hospital faz, com urgência, uma notificação à Central de Notificação, Captação e Distribuição de Órgãos da região (CNCDO). Essa notificação é uma exigência determinada no art. 18 do Decreto n. 2.268, de 30.06.1997.

Atualmente, a legislação determina a constituição de Comissão Intra- Hospitalar de Doação de Órgãos e Tecidos para Transplante (CIHDOTT) para alguns tipos de hospitais, a saber: (i) os hospitais públicos, privados e filantrópicos com mais de duzentos óbitos por ano e leitos para assistência ventilatória (em terapia intensiva ou emergência), e que tenha profissionais da área de medicina interna ou pediatria ou intensivismo, ou neurologia ou neurocirurgia ou neuropediatria, integrantes de seu corpo clínico; (ii) estabelecimento de saúde de referência para trauma e/ou neurologia e/ou neurocirurgia com menos de mil óbitos por ano; (iii) estabelecimento de saúde não oncológico, com duzentos a mil óbitos por ano; e (iv) estabelecimento de saúde não oncológico com mais de mil óbitos por ano ou estabelecimento de saúde com pelo menos um programa de transplante de órgão.

As CIHDOTT's são responsáveis, dentre outros, por coordenar em âmbito hospitalar o processo de doação/transplante, identificando os potenciais doadores, agilizando o diagnóstico de morte encefálica, responsabilizando-se pelas entrevistas familiares e educação continuada dos funcionários.

Assim, voltando ao cerne da questão, uma vez confirmado o diagnóstico de morte encefálica, o médico responsável pelo paciente deverá comunicar à família. Ato contínuo, a CIHDOTT do hospital fará a entrevista familiar para a doação de órgãos. Caso a família não autorize a doação dos órgãos/tecidos, interrompe-se todo o processo ${ }^{(14)}$. Todavia, se a família desejar fazer a doação, a CIHDOTT providenciará o preenchimento e assinatura do Termo de Doação de Órgãos e Tecidos por parte da família.

Uma vez concedida a autorização, a CNCDO providenciará toda a logística para iniciar o processo de captação e distribuição dos órgãos/tecidos.

\footnotetext{
(14) Merece ser anotado que os diversos ordenamentos jurídicos do mundo têm dado tratamento diverso às normas que cuidam da disposição de órgãos e tecidos, sendo possível classificar em três sistemas: (I) um sistema de manifestação compulsória; (ii) um sistema de consentimento presumido; e (iii) um sistema de consentimento. Cf. PEDRA, Adriano Sant'Ana. Transplantes de órgãos de anencéfalos. Revista de Direito Sanitário, São Paulo, v. 8, n. 3, p. 174, nov. 2007/fev.2008.
} 
Para a retirada de órgãos e tecidos é preciso o envolvimento de várias equipes de profissionais ligados ao centro cirúrgico e especialistas de cada área, de acordo com o órgão que será captado.

Insta frisar: a captação de órgãos e tecidos só poderá ocorrer após a autorização e assinatura do termo de doação pelo cônjuge ou parente maior de idade, de até $2^{\circ}$ grau, e na presença de testemunhas.

Os órgãos e tecidos somente serão utilizados para transplante se os exames demonstrarem que o doador não possuía qualquer doença que possa oferecer riscos ao receptor. Assim, nos moldes do art. 47 da Portaria n. 2.600/09, todos os potenciais doadores falecidos de órgãos, tecidos, células ou partes do corpo deverão ser submetidos, antes da alocação dos enxertos, a diversos procedimentos médicos e testes de compatibilidade, com vistas à segurança do receptor.

Os testes serão diferentes para cada tipo de órgão ou tecido doado. Assim, por exemplo, se órgão doado for um rim, haverá uma bateria de testes específicos à utilidade e compatibilidade deste órgão. A Portaria n. 2.600/09 é criteriosa quanto a estes testes. Há no seu bojo subdivisões que tratam de cada tipo de órgão ou tecido e, consequentemente, de cada tipo de procedimento médico e testes a serem realizados com cada tipo de órgão ou tecido. Como foi dito, o rigor do procedimento tem como finalidade a segurança e saúde do possível receptor.

Com os testes realizados, o órgão é disponibilizado para doação. Com base nos dados do doador e do órgão/tecido a ser doado, busca-se na lista única de receptores, gerenciada por um sistema nacional, o primeiro da lista.

\subsection{A lista única de receptores}

Entre as estratégias utilizadas pelo Poder Público para solucionar o problema da escassez dos órgãos para transplantes, merece destaque a questão dos mecanismos e critérios de seleção de pacientes que deveriam se beneficiar do transplante de órgãos e tecidos, com vistas a garantir maior efetividade e otimização para a utilização dos órgãos doados.

No Brasil, o mecanismo de seleção do receptor que primeiro receberá o órgão ou tecido doado é a lista única de espera. A referida lista foi criada pelo Ministério da Saúde em 1997, e elenca todas as pessoas, de norte a sul do país, que aguardam qualquer tipo de transplante.

A lista única nacional de receptores veio atender a uma reivindicação antiga, pois as pessoas esperam, em média, dois anos por um transplante. Eram constantes os casos de familiares que doavam para pessoa específica, com possível comércio ou receptores com algum tipo de notoriedade, 
como aconteceu com o comediante Mussum, que recebeu um transplante de coração sem a angústia da espera. Os que não tinham fama ou dinheiro ficavam anos na fila, e acabavam morrendo antes de conseguir o transplante ${ }^{(15)}$.

Inicialmente, o critério adotado era o da ordem cronológica de inscrição. Assim, aquele que primeiro se inscrevesse, independentemente de seu estado de saúde ser melhor ou pior do que o daquele que o sucede na lista, receberia antes a tão sonhada doação.

Ocorre que, como já era de se esperar, tal critério, na prática, mostrou-se insuficiente, ineficaz e sobremaneira injusto, porquanto tinha como fator determinante a ordem de inscrição do paciente da fila espera. Tal método, obviamente, nunca atendeu à realidade, haja vista não ser aquele que primeiro se inscreveu na lista, necessariamente, quem está mais próximo de ser fatalmente vitimado por sua doença ${ }^{(16)}$.

Neste compasso, emergiu a necessidade de serem estabelecidos critérios técnicos, calcados na realidade de cada paciente, conciliando o tempo de espera com os avanços da ciência médica na avaliação de riscos e benefícios no momento da realização do transplante. Consequentemente, pessoas que não estavam em posição privilegiada na lista conseguiram passar à frente, pois não gozavam de condições para aguardar a longa espera para o recebimento de um órgão(17).

A atual lista única de saúde se regula nestes moldes. Neste sentido, a Portaria n. 2.600/09 dispõe que o Sistema de Lista Única é constituído pelo conjunto de potenciais receptores brasileiros, natos ou naturalizados, ou estrangeiros residentes no país inscritos para recebimento de cada tipo de órgão, tecido, célula ou parte do corpo. Ainda segundo a portaria, a lista única é regulada por um conjunto de critérios específicos para a distribuição deles a estes potenciais receptores, assim constituindo o Cadastro Técnico Único (CTU).

A inscrição dos pacientes no CTU é feita pelo estabelecimento de saúde e/ou pela equipe responsável pelo seu atendimento no CNCDO com atuação na área de sua residência. O paciente, além de informado dos seus direitos, dos riscos e deveres a que se submeterá, fará uma série de exames que comporão seu quadro clínico e de compatibilidade para fins de eventual transplante. Vale destacar que este dados, juntamente com a cronologia da

(15) ASSOCIAÇÃO BRASILEIRA DE TRANSPLANTE DE ÓRGÃOS. Disponível em: <www.abto.org.br/ abtov02/portugues/jbt/vol9n_1/materiaCompleta.pdf>. Acesso em: 21 jul. 2010.

(16) LIMA, Lucas Rister de S.; FERREIRA, Maria Beatriz Crespo. O princípio da reserva do possível, o direito à saúde e a fila para transplante de órgãos. Revista de Direito Privado, São Paulo, n. 41, p. 123, jan./mar. 2010.

(17) Id., loc. cit. 
inscrição, serão levados em consideração na ordem da fila única de recepção. Desta forma, a lista única de receptores será constituída por candidatos sem restrições no momento da distribuição de um órgão de doador falecido(18).

A lista única de receptores, embora tenha abrangência nacional, possui como critério prioritário a doação em âmbito estadual. Isto ocorre porque os órgãos disponibilizados para doação são primeiramente direcionados para a área do CNDCO do doador, e, caso não haja possibilidade de aproveitamento no próprio Estado, serão disponibilizados para a Central Nacional.

Como se nota, a triagem de doação estabelecida pela lista única de doadores respeita uma série de critérios técnicos para doação, dentre os quais o critério cronológico, que é apenas um dos parâmetros a serem observados. Por questão de política legislativa, aliada à logística de transporte e tempo máximo de espera do órgão, foram estabelecidas prioridades regionais, segundo as quais o órgão será prioritariamente doado na região do CNDCO que foi captado, e, sucessivamente na macrorregião no qual o CNDCO se localiza, para posteriormente ser disponibilizado para o restante do país.

\section{CRIAÇÃO DE MICRORREGIÕES COMO CRITÉRIO DE PRIORIDADE}

Conforme visto, a formação da fila nacional de transplantes de órgãos no Brasil é pautada em critérios técnicos, de forma a maximizar a possibilidade de vida de cada um dos pacientes que dependem de um transplante. A questão cronológica de inscrição na fila, embora seja muito importante, não é mais preponderante que a compatibilidade entre doador e receptor e o risco de vida dos receptores.

Além deste critério técnico de formação de cadastro, a fila de transplantes também respeita um critério de prioridades regionais. $O$ órgão doado primeiro deve ser destinado à unidade federativa na qual foi destacada sua disponibilidade, para só depois, caso não seja utilizado, ser oferecido à macrorregião na qual a unidade federativa se encontra, e, por fim, ao sistema nacional.

Deve ser evidenciado que o critério de prioridade estadual apresenta-se como política legislativa desamparada de questões técnicas na sua formatação. Diante dessa premissa, não há qualquer impedimento à revisão de tais critérios envolvendo, inclusive, a participação popular na sua formatação.

(18) ASSOCIAÇÃO BRASILEIRA DE TRANSPLANTE DE ÓRGÃOS. Disponível em: <www.abto.org.br/ abtov02/portugues/jbt/vol9n_1/materiaCompleta.pdf>. Acesso em: 21 jul. 2010. 
Cabe destacar que o Poder Público deve prestar as políticas públicas com o máximo de eficiência, certo que "a proteção dos direitos fundamentais impõe ao Estado o dever de adotar uma organização e procedimentos justos"(19).

Vale consignar que a participação popular no processo de doação de órgãos e, in casu, no controle da fila de doação de órgãos é inerente ao próprio Sistema Único de Saúde, pois este sistema é direcionado pelo princípio da participação da comunidade, tanto no que diz respeito à definição quanto no que tange ao controle social das ações e políticas de saúde. Como bem ressaltam Ingo Sarlet Wolfgang e Mariana Filchtiner Figueiredo, de uma maneira geral, a participação da sociedade

se realiza por meio dos representantes da sociedade civil junto às sucessivas Conferências de Saúde, que têm competência para fazer proposições às políticas de saúde em cada um dos níveis da federação (cujo modelo mais marcante permanece sendo a VIII Conferência Nacional de Saúde, ainda antes de 1988); perante os Conselhos de Saúde, que atuam no planejamento e controle do SUS, aí incluído o financiamento do sistema, bem como na viabilização de um canal para a participação popular, com a análise de propostas e denúncias; e, ainda, no âmbito das agências reguladoras (Agência Nacional de Vigilância Sanitária - ANVISA, Câmara de Saúde Suplementar da Agência Nacional de Saúde Suplementar - ANS, Conselho Nacional de Meio Ambiente - CONAMA etc.). ${ }^{(20)}$

Ainda segundo Ingo Wolfgang Sarlet, é de suma importância a participação popular, visto que provoca a

densificação de uma especial dimensão dos direitos fundamentais, que, no contexto dos direitos a prestações em sentido amplo, atuam como direitos de participação na organização e no procedimento, evidenciando a faceta democrático-participativa, in casu, do direito à saúde, a retomar a ideia de um status activus processualis, tal qual defendida, desde há muito, por Peter Häberle.(21)

Portanto, mediante a participação popular, a Constituição assegura que os próprios indivíduos interajam no processo de definição das políticas públicas de saúde, intervindo sobre como se dará a efetivação desse direito fundamental, além de, posteriormente, exercerem o controle social sobre essas mesmas ações.

(19) LOUREIRO, João Carlos Simões Gonçalves. Transplantações: um olhar constitucional. Coimbra: Coimbra Ed., 1995. p. 34.

(20) SARLET, Ingo Wolfgang; FIGUEIREDO, Mariana Filchtiner. op. cit., p. 143-144.

(21) SARLET, Ingo Wolfgang. Os direitos fundamentais, sua dimensão organizatória e procedimental e o direito à saúde: algumas aproximações. Revista de Processo, São Paulo, n. 175, p. 25, set. 2009. 
Aqueles que vivenciam a Constituição são quem mais têm legitimidade para transformá-la em realidade e fazer a democracia desabrochar do papel. É preciso que o direito constitucional seja um direito vivo, o que só é possível imaginar com uma concretização da Constituição com a presença ativa do cidadão(22).

Ainda a ressaltar o aspecto positivo da participação popular no processo de organização da fila de transplante de órgãos, convém mencionar que é da essência de alguns direitos fundamentais a participação popular na organização do seu procedimento de concretização. Como bem enfatiza Ingo Wolfgang Sarlet,

a fruição de diversos direitos fundamentais não se revela possível ou, no mínimo, perde em efetividade, sem que sejam colocadas à disposição prestações estatais na esfera organizacional e procedimental; além disso, importa considerar que importantes liberdades pessoais somente atingem um grau de efetiva realização no âmbito de uma cooperação (no sentido de atuação conjunta e ordenada) por parte de outros titulares de direitos fundamentais, implicando prestações estatais de cunho organizatório e coordenatório, em regra de natureza normativa. ${ }^{(23)}$

Destarte, é com lastro nestas constatações que se verifica a necessidade dos assim denominados direitos de participação na organização e procedimento (ou direitos à organização e ao procedimento),(24) como, por exemplo, o direito de participação popular na formatação da fila de transplantes de órgãos.

Assim, voltando ao cerne da questão, deve-se mencionar que o critério de prioridade estadual hoje vigente não atende aos anseios da sociedade, uma vez que não proporciona o acompanhamento efetivo das doações realizadas, criando barreira a uma maior aderência às campanhas que estimulam as doações de órgãos.

Convém consignar que é no local onde mora que o cidadão poderá iniciar um amplo processo de transformação, mediante participação nas decisões que lhe afetam direta ou indiretamente. No espaço local, apresentam-se as melhores condições para a participação popular, mormente em razão da maior possibilidade de identificação dos interesses comuns e dos meios para a sua realização ${ }^{(25)}$.

(22) PEDRA, Adriano Sant'Ana. A Constituição viva: poder constituinte permanente e cláusulas pétreas, cit., p. 326.

(23) SARLET, Ingo Wolfgang. op. cit., p. 24.

(24) Id. loc., cit.

(25) PEDRA, Adriano Sant'Ana. Democracia participativa no município. In: SOUSA, Horácio Augusto Mendes de; FRAGA, Henrique Rocha (Coords.). Direito municipal contemporâneo: novas tendências. Belo Horizonte: Fórum, 2010. p. 63. 
Nesse sentido, ao encontro da participação popular no processo de formatação da fila de doação de órgãos, melhor seria se pudesse ser estabelecida prioridade de atendimento por microrregiões, ou seja, que a organização de listas de espera fosse formada em torno de polos regionais dentro de uma unidade federativa, reduzindo a área de abrangência para a aplicação dos critérios de prioridade da fila de espera.

Com a diminuição da área de abrangência, seria possível um acompanhamento mais efetivo por parte dos cidadãos no processo de doação de órgãos. Trata-se de um processo de abertura de participação política por aproximação, na medida em que se diminui o hiato existente entre o Estado controlador da fila de transplantes de órgãos e os indivíduos doadores, receptores ou interessados de alguma forma.

Vale dizer que esta aproximação é verificada pelo fato de que, quanto menor a abrangência da área geográfica para a aplicação do critério de prioridade, mais a população terá condições de perceber os efeitos de uma doação efetivada, sensibilizando todos acerca da importância da doação de órgãos e tecidos.

Além de aproximação, a mudança do critério de prioridade para um padrão microrregional proporcionaria ainda maior transparência no sistema de doação de órgãos. A lisura no processo de doação de órgão fragiliza os obstáculos existentes. É que, ao longo dos anos, muita crendice popular afastou (e ainda afasta) potenciais doadores. Assim, a aproximação popular viabilizada pela criação de microrregiões teria o condão de gerar como primeiro efeito a derrubada de mitos acerca da doação de órgãos e, consequentemente, poderia proporcionar uma maior adesão da população no processo de doação de órgãos.

Com a proximidade e com a lisura, o critério de prioridade por microrregiões teria ainda como efeito indireto o aumento das doações de órgãos, porquanto com o envolvimento popular em todo o processo de captação e doação de órgãos espera-se que ocorra uma mobilização maior em torno da questão. A divisão em microrregiões permitiria que o povo visse os resultados, na medida em que as doações teriam preferências para um grupo menor, formado por pessoas mais próximas. Isto poderia motivar novas doações.

$\mathrm{Na}$ concretização do direito à saúde por intermédio dos transplantes de órgãos, o Estado depende muito do altruísmo da sociedade. Logo, é imprescindível que o Estado se abra à participação popular como forma de fomentar a mobilização popular em torno da questão.

\section{CONSIDERAÇÕES FINAIS}

Desde o primeiro transplante de órgão registrado, mais de cinco décadas se passaram. Com o avanço das técnicas e o aprimoramento de drogas contra a rejeição, hoje praticamente todos os órgãos do corpo são 
passíveis de substituição. Os transplantes de órgãos são uma realidade da medicina há muitos anos e, nesta busca por prolongar a vida, o Brasil desponta com o maior sistema público de transplantes do mundo, com um esquema de filas, hoje, organizado.

Embora se constate grandes avanços na organização da fila de transplantes de órgãos no Brasil, é certo que sua legitimidade, bem como a legitimidade de toda a organização do Sistema Nacional de Transplante de Órgãos, imprescinde de uma efetiva participação popular. Em um Estado Democrático de Direito, o crivo para a legitimidade de qualquer ação ou política estatal é a vontade soberana do povo exercida pelos meios legais.

Nos termos da Portaria n. 2.600/09, do Ministério da Saúde, a organização da fila de transplantes de órgãos no Brasil é majoritariamente pautada em critérios técnicos. Apesar da prevalência de tais critérios, a fila de doações de órgãos também é regida por prioridade estadual, porquanto os órgãos disponibilizados para doação são primeiramente direcionados para a unidade federativa do doador. É precisamente neste ponto que se faz indispensável a participação popular.

Vale consignar que é da essência dos direitos fundamentais a participação popular na sua concretização. Assim, a formatação da fila de transplantes de órgãos, na condição de instrumento à concretização do direito fundamental à saúde, deve ser aberta à participação popular.

$\mathrm{Na}$ específica situação dos transplantes de órgãos, a participação popular deve ocorrer por aproximação. Ou seja, ao invés da adoção da prioridade de transplantes por Estados, com vistas à participação popular, melhor seria a adoção de prioridade por microrregiões. A criação de microrregiões, diretamente, teria o condão de diminuir a área de abrangência para doação de órgão, e, indiretamente, traria como benefícios (i) um acompanhamento efetivo das doações realizadas por parte da população; (ii) uma facilitação no controle do processo de doação e no controle do funcionamento da própria fila de transplante de órgãos e (iii) uma maior aderência às campanhas que estimulam as doações de órgãos.

A simples mudança no critério de prioridade estadual para o critério de microrregião, no processo de doação de órgãos, não só atenderia a necessidade de participação popular inerente ao Estado Democrático de Direito, como também contribuiria para melhoria do Sistema Nacional de Transplante de Órgãos.

\section{REFERÊNCIAS BIBLIOGRÁFICAS}

ASSOCIAÇÃO BRASILEIRA DE TRANSPLANTE DE ÓRGÃOS. Disponível em: <www.abto.org.br/abtov02/portugues/jbt/vol9n_1/materiaCompleta.pdf $>$. Acesso em: 21 jul. 2010. 
DINIZ, Maria Helena. O estado atual do biodireito. 3. ed. São Paulo: Saraiva, 2006.

GORDILLO, Agustin. Participation in Latin America. Nova York: Vintage Press, 1982.

LEITE, Carlos Henrique Bezerra. Os direitos da personalidade na perspectiva dos direitos humanos e do direito constitucional do trabalho. Depoimentos Revista de Direito das Faculdades de Vitória, Vitória, n. 9, p. 49-69, jan./dez. 2005.

LIMA, Lucas Rister de S.; FERREIRA, Maria Beatriz Crespo. O princípio da reserva do possível, o direito à saúde e a fila para transplante de órgãos. Revista de Direito Privado, São Paulo, n. 41, p. 106-132, jan./mar. 2010.

LOUREIRO, João Carlos Simões Gonçalves. Transplantações: um olhar constitucional. Coimbra: Coimbra Ed., 1995.

MINISTÉRIO DA SAÚDE. Disponível em <http://www.adote.org.br/pdf/ lista0607.pdf>. Acesso em: 23 jul. 2010.

Sistema Nacional de Transplantes. Disponível em: <http://snt. datasus.gov.br/ SNT/index.jsf>. Acesso em: 22 jul. 2010.

MOREIRA NETO, Diogo de Figueiredo. Direito da participação política. Rio de Janeiro: Renovar, 1992.

PEDRA, Adriano Sant'Ana. A Constituição viva: poder constituinte permanente e cláusulas pétreas. Belo Horizonte: Mandamentos, 2005.

Democracia participativa no município. In: SOUSA, Horácio Augusto Mendes de; FRAGA, Henrique Rocha (Coords.). Direito municipal contemporâneo: novas tendências. Belo Horizonte: Fórum, 2010.

Transplantes de órgãos e o biodireito constitucional. Revista de Direito Constitucional e Internacional, São Paulo, ano 15, n. 61, p. 7-24, out./dez. 2007.

- Transplantes de órgãos de anencéfalos. Revista de Direito Sanitário, São Paulo, v. 8, n. 3, p. 167-179, nov. 2007/fev. 2008.

SARLET, Ingo Wolfgang; FIGUEIREDO, Mariana Filchtiner. Algumas considerações sobre o direito fundamental à proteção e promoção da saúde aos 20 anos da Constituição Federal de 1988. Revista de Direito do Consumidor, São Paulo, n. 67, 125-172, jul./set. 2008.

Os direitos fundamentais, sua dimensão organizatória e procedimental e o direito à saúde: algumas aproximações. Revista de Processo, São Paulo, n. 175, p. 9-33, set. 2009.

SILVA, José Afonso da. Curso de direito constitucional. 30. ed. São Paulo: Malheiros, 2008. 